\title{
ANALISIS FAKTOR SOSIAL DAN PSIKOLOGI SEBAGAI PENENTU KEPUASAN PENGUNJUNG TAMAN KOTA DAN TAMAN HUTAN KOTA DI DKI JAKARTA
}

\section{(Analysis of Social and Psychological Factors Determining Satisfaction of Visitors to Urban Parks and Urban Forests Parks in DKI Jakarta)}

\author{
RENo CATElya Dira OKTAVIA ${ }^{1 *}$, HERMANTO SIREGAR $^{2)}$, TUtUT SUNARMINTO ${ }^{3)}$ DAN RACHMAD \\ HERMAWAN ${ }^{3)}$
}
1) Program Studi Manajemen Ekowisata dan Jasa Lingkungan, Fakultas Kehutanan, Kampus IPB Dramaga, Bogor 16680, Indonesia

2) Departemen Ekonomi, Fakultas Ekonomi dan Manajemen, Kampus IPB Dramaga, Bogor 16680, Indonesia

3) Departemen Konservasi Sumberdaya Hutan dan Ekowisata, Fakultas Kehutanan, Kampus IPB Dramaga, Bogor 16680, Indonesia

*Email: reno_cdo@yahoo.com

Diterima 30 April 2019 / Disetujui 04 Agustus 2020

\begin{abstract}
Social and psychological factors also greatly influence the level of satisfaction of visitors during recreation in urban parks and urban forests parks (THK) in the Capital Special Area (Daerah Khusus Ibu Kota/DKI) Jakarta. This study aims to analyze social and psychological factors in urban parks and urban forests in relation to the level of visitor satisfaction. Data were collected from respondents with que stionnaire tools, applying the One Score One Indicator Scoring System. The number of respondents was 600 people using the Purposive Sampling Method. Data analysis using the Importance Performance Analysis Method, Customer Satisfaction Index, correlation and regression statistical analysis. The results showed that there were 5 social and psychological aspects that influenced the level of visitor satisfaction. Aspects that have high importance and high satisfaction values are aspects of dynamic activities, while those of low value are security and safety aspects. Spearman Correlation Analysis shows that from the five social and psychological aspects one another has a level of association or relationship that is very close to a positive coefficient value. Based on regression analysis of visitor satisfaction; dynamic aspects of activities, aspects of recreational activities, aspects of comfort have a significant effect, while aspects of social contact and safety and security factors have no significant effect on visitor satisfaction.
\end{abstract}

Keywords: psychology, social, urban forest parks, urban parks, visitor satisfaction

\section{ABSTRAK}

Faktor sosial dan psikologi sangat berpengaruh terhadap tingkat kepuasan pengunjung selama berekreasi di taman kota dan taman hutan kota (THK) dalam wilayah DKI Jakarta. Penelitian ini bertujuan untuk menganalisis faktor sosial dan psikologi di dalam taman kota dan THK dalam kaitannya dengan tingkat kepuasan pengunjung. Data penelitian dikumpulkan dari responden dengan alat bantu kuesioner, menerapkan pola One Score One Indicator Scoring System. Jumlah responden sebanyak 600 orang dengan metode purposive sampling. Analisis data menggunakan metode importance performance analysis, customer satisfaction index, analisis statistik korelasi dan regresi. Hasil penelitian menunjukkan bahwa terdapat lima aspek sosial dan psikologi yang mempengaruhi tingkat kepuasan pengunjung. Aspek yang memiliki nilai kepentingan tinggi dan nilai kepuasan tinggi adalah aspek atmosfer berkegiatan, sedangkan yang bernilai rendah adalah aspek keamanan dan keselamatan. Analisis korelasi Spearman menunjukkan bahwa dari kelima aspek sosial dan psikologi tersebut satu sama lain memiliki tingkat asosiasi atau hubungan yang sangat dekat dengan nilai koefisien yang positif. Berdasarkan analisis regresi kepuasan pengunjung; aspek atmosfer berkegiatan, aspek aktivitas rekreasi, aspek kenyamanan berpengaruh secara signifikan, sedangkan aspek kontak sosial dan faktor keamanan dan keselamatan tidak berpengaruh signifikan terhadap kepuasan pengunjung.

Kata kunci: kepuasan pengunjung, psikologi, sosial, taman kota, taman kota hutan kota (THK)

\section{PENDAHULUAN}

Keberadaan Ruang Terbuka Hijau (RTH) khususnya taman kota dan THK di kota besar sudah menjadi suatu tuntutan sekaligus harus diusahakan dan dijaga dalam kehidupan modern yang menginginkan suasana yang lebih segar dan alami serta untuk estetika wilayah perkotaan. Taman kota dan THK di wilayah perkotaan dapat memberikan kebutuhan ruang bagi sisi humanis manusia yakni kebutuhan dan kenikmatan berinteraksi antar sesama manusia, antar manusia dengan lingkungan dan alam dalam sebuah ruang publik (Kabisch et al. 2015). Selain itu, taman kota dan THK juga memberikan kebutuhan terhadap ruang bagi manusia untuk menghabiskan leisure time atau waktu luang dimana mereka bebas melakukan aktivitas lain setelah berbagai existence and subsistence activies terpenuhi (Avenzora 2008).

Konijnendijk et al. (2004) menyatakan bahwa RTH termasuk di antaranya THK yang memiliki tiga nilai 
manfaat: (1) nilai ekonomi dan sumber penghidupan masyarakat, (2) nilai ekologis dan kehati, (3) nilai sosial dan budaya. Nilai sosial budaya diwujudkan dalam bentuk kegiatan rekreasi bagi masyarakat perkotaan. Lebih lanjut disebutkan bahwa rekreasi di alam terbuka pada taman kota dan THK menjadi pilihan masyarakat perkotaan yang tinggal dekat dengan RTH (Eriksson dan Nordlund 2013). Kegiatan rekreasi di THK dapat memberikan dampak positif terhadap aspek kesehatan fisik dan mental juga upaya untuk mengurangi stress (Tabbush and O’Brien 2003).

Kegiatan rekreasi di RTH khususnya taman kota dan THK semakin meningkat secara signifikan dalam beberapa tahun terakhir dan menjadi bagian penting dalam life style keseharian masyarakat kota, seperti yang juga terjadi di Korea Selatan (Shin et al. 2005). Mereka dapat melakukan berbagai kegiatan rekreasi di taman kota dan THK, seperti berjalan kaki, berlari, bersepeda, bermain, berolahraga, duduk-duduk, berfoto, berkumpul (Santos et al. 2016). Konijnendijk (2003) menyebutkan bahwa pemanfaatan THK untuk tujuan rekreasi sudah umum dilakukan di Eropa. Di Swedia, sekitar 55\% wisatawan yang berkunjung ke hutan memilih untuk mengunjungi THK untuk tujuan rekreasi, sedangkan di Perancis antara 1/4 sampai dengan $1 / 2$ wisatawan hutan memilih mengunjungi kawasan THK di Greater Paris Region setiap tahunnya. Wilkes-Allemann et al. (2015) menyebutkan bahwa $98 \%$ populasi penduduk Swiss pada umumnya mengunjungi THK untuk tujuan rekreasi.

Salah satu indikator keberhasilan pengelolaan taman kota dan THK untuk tujuan rekreasi adalah tingkat kepuasan pengunjung yang optimal dengan tetap menjaga nilai kehati dan nilai ekonomi masyarakat sekitar. Faktor-faktor yang mempengaruhi tingkat kepuasan pengunjung di THK dapat berupa faktor biofisik dan faktor non biofisik (ekonomi, sosial dan psikologi). Peneliti membagi faktor biofisik meliputi 1) aspek ekologis, 2) aspek iklim mikro, dan 3) aspek fasilitas pendukung. Adapun faktor ekonomi, sosial dan psikologi meliputi : 1) aspek ekonomi pendukung, 2) aspek kontak sosial, 3) aspek atmosfer berkegiatan, 4) aspek aktivitas rekreasi, 5) aspek keamanan dan keselamatan serta 6) aspek kenyamanan. Penelitian tentang pengaruh faktor biofisik terhadap kepuasan pengunjung telah dilakukan oleh beberapa peneliti dalam dekade terakhir ini, seperti yang dilakukan oleh Wang et al. (2016) di Taiwan sedangkan aspek sosial dan

Pengambilan data intensitas kepuasan pengunjung dari asepek sosial dan psikologi dilakukan melalui penyebaran kuesioner yang dirancang untuk mengetahui persepsi pengunjung terhadap pengaruh kepadatan pengunjung dengan nilai kepuasan; hal ini juga untuk mengetahui kebiasaan pengunjung (visitors behaviours) ketika berada di RTH yang dikunjungi sebagai tapak rekreasi yang dapat menjadi informasi penting bagi pihak pengelola (Sanesi et al. 2007). Kuesioner yang digunakan adalah bersifat close ended yang dirancang psikologi belum terlalu banyak dilakukan penelitian secara lebih mendalam (Deng et al. 2017).

Berdasarkan hal tersebut maka diperlukan suatu penelitian yang mendalam untuk mengetahui faktor sosial dan psikologi apa saja yang dapat memaksimalkan kepuasan pengunjung. Adapun tujuan penelitian adalah menganalisis faktor sosial dan psikologi ditaman kota dan THK dalam kaitannya dengan tingkat kepuasan pengunjung sehingga hasilnya dapat menjadi salah satu masukan yang mendasari tindakan pihak pengelola tapak rekreasi dalam menerapkan arah dan pola kebijakan manajemen pengelolaan tapak.

\section{METODE PENELITIAN}

Penelitian dilaksanakan selama lima bulan yang meliputi: a) survei awal, b) pengumpulan data selama dua minggu pada bulan Oktober 2018 sampai bulan November 2018, pengambilan sampel responden (pengunjung) dilakukan dalam dua jenis hari kunjungan, yaitu hari kerja (antara Senin hingga Jumat) dan akhir pekan (Sabtu dan Minggu) dan c) pengolahan dan analisis data. Penentuan lokasi penelitian dilakukan dengan Purposive Sampling Method, yang mewakili kriteria: a) well established area (Taman Kota Suropati di Jakarta Pusat), b) established area (THK Honda-Tebet di Jakarta Selatan), c) less established area (THK Penjaringan di Jakarta Utara). Dalam penentuan kriteria lokasi penelitian, peneliti membagi kriteria wilayah penelitian dengan menelusuri jalur ekologi/jalur sungai yang mengalir dari arah Wilayah Selatan DKI Jakarta (yang berasal dari daerah pegunungan di luar Wilayah DKI Jakarta) menuju ke zona pesisir di pantai Wilayah Utara DKI Jakarta; pembagian zona menjadi tiga tipe area berdasarkan: a) aspek administratif, aspek fungsionalnya dan sistem kewilayahan struktur ruang dan pola ruang yang mempunyai jangkauan pelayanan pada tingkat wilayah (UU No. 26 Tahun 2007, Pasal 1 dan 18), b) pola penggunaan lahan; pusat kota dianggap sebagai wilayah yang mempunyai harga lahan yang paling mahal dan aksesbilitas yang paling tinggi (Ratcliff 1949), c) pola nilai lahan; mulai dari pusat kota ke pinggir kota mengalami penurunan (Berry 1963), d) pertumbuhan kota besar secara terintregrasi menyebar dimulai dari pusat kota ke pinggir kota sebagai kesatuan sistem perkotaan yang kompleks dengan terbentuknya spesialisasi dan diferensiasi ruang dalam proses pertumbuhannya (Harris dan Ullman 1945).

dengan mengadopsi Metoda One Score One Criteria Scoring System (Avenzora 2008) yang memiliki rentang skor 1-7 yang bersifat ascending dan berasal dari Skala Likert (yang diperluas nilai skornya; skor 1 = sangat rendah, skor $2=$ rendah, skor $3=$ agak tidak rendah, skor $4=$ biasa saja, skor $5=$ agak tinggi, skor $6=$ tinggi, skor 7 = sangat tinggi).

Jumlah sampel responden per periode waktu kunjungan mengacu pada Roscoe (1982 dalam Sugiyono 2012) dan Slovin (1960 dalam Fellegi 2003) yaitu jika 
sampel dibagi dalam kategori, maka jumlah anggota sampel setiap kategori minimal 30 responden. Atas dasar tersebut maka total responden adaah 600 orang. Sampel responden (pengunjung) diambil dalam dua tipe hari kunjungan, yaitu weekdays (antara Senin hingga Jumat) dan weekend (Sabtu dan Minggu). Pada tiap hari kunjungan dilaksanakan pengambilan data dalam empat periode pembagian waktu, yaitu periode 1 (04.00 WIB 10.00 WIB), periode 2 (10.00 WIB - 16.00 WIB), periode 3 (16.00 WIB - $22.00 \mathrm{WIB})$, dan periode 4 (22.00 WIB - 04.00 WIB).

Faktor sosial dan psikologi kepuasan pengunjung diidentifikasi dari lima aspek penting yaitu: a) dari kelompok faktor sosial terdapat tiga aspek yang diteliti meliputi aspek kontak sosial, aspek atmosfer berkegiatan, aspek aktivitas rekreasi, dan b) dari kelompok faktor psikologi terdapat dua aspek yang diteliti meliputi aspek keamanan dan keselamatan, aspek kenyamanan. Analisa faktor sosial dan psikologi penentu kepuasan pengunjung taman kota dan THK di DKI Jakarta menggunakan teknik analisis kuantitatif dan kualitatif dengan memanfaatkan metode Importance Performance Analysis (IPA) dan Customer Satisfaction Index (CSI). CSI digunakan untuk mengetahui tingkat kepuasan pengunjung secara menyeluruh dengan melihat tingkat kepentingan dari indikator-indikator produk atau jasa (Aritonang 2005). IPA (analisis kuadran) bertujuan untuk mengelompokkan persepsi nilai kepentingan dan nilai kepuasan (Algifari 2016), dan digunakan agar secara deskriptif dapat dipetakan hubungan antara kepentingan dengan kepuasan dari masing-masing indikator untuk kemudian dapat dianalisis tingkat kepuasan responden secara keseluruhan dan juga dapat digunakan pula untuk menganalisis secara deskriptif kinerja pengelola tapak rekreasi (Martilla dan James 1977). Hasil perhitungan rata-rata nilai kepentingan dan nilai kepuasan yang diperoleh pada masing-masing indikator dipetakan dalam Diagram Kartesius, seperti terlihat pada Gambar 1. Dari ke 4 kuadran dapat dilihat kinerja keberadaan yang tersedia di THK terhadap masing-masing indikator terkait pada tiap aspek penilaian dan dimanfaatkan untuk mengidentifikasi prioritas beberapa indikator terkait kualitas yang harus segera diperbaiki, dipertahankan, dapat diabaikan yang kemudian diharapkan menghasilkan formula kebijakan manajemen dalam perbaikan kualitas produk/jasa ditapak rekreasi. Pemanfaatan pembagian menjadi 4 kuadran adalah agar dapat dipetakan pola kebutuhan dari nilai kepentingan dan kepuasan sehingga dapat diformulasikan arah kebijakan yang menjadi tanggung jawab pengelola tapak rekreasi. Kuadran 1 menunjukkan indikator yang dianggap penting dan memiliki kepuasan tinggi (pertahankan prestasi: harus dikelola lebih baik lagi), kuadran 2 memuat indikator yang dianggap penting tapi mempunyai nilai kepuasan dibawah harapan pengunjung (prioritas utama: tantangan untuk meningkatkan performa), kuadran 3 menunjukkan indikator yang dianggap kurang penting dan nilai kepuasan rendah (dapat diabaikan), kuadran 4 memuat indikator yang kurang penting tetapi mempunyai nilai kepuasan tinggi (berlebihan).

Selanjutnya, untuk mengetahui hubungan antar faktor sosial dan psikologi terhadap kepuasan pengunjung taman kota dan THK dianalisis dengan statistik inferensia yaitu analisis korelasi Spearman dan analisis regresi berganda.

\section{HASIL DAN PEMBAHASAN}

\section{Profil Umum Ketiga Tapak Penelitian}

Taman Kota Suropati mempunyai total luas area $16.570,16 \mathrm{~m}^{2}$, luas tanaman hias $906,88 \mathrm{~m}^{2}$, luas rumput 9.153,09 $\mathrm{m}^{2}$ (tidak boleh diinjak), dengan total jumlah pepohonan 308 pohon yang terdiri dari jenis mahoni (Swietenia macrophylla) dan jenis trembesi (Samanea saman). Sebagai RTH, Taman Kota Suropati masuk dalam kategori taman kota yang terbuka untuk umum selama 24 jam dan tidak berbayar/ tanpa tiket masuk.

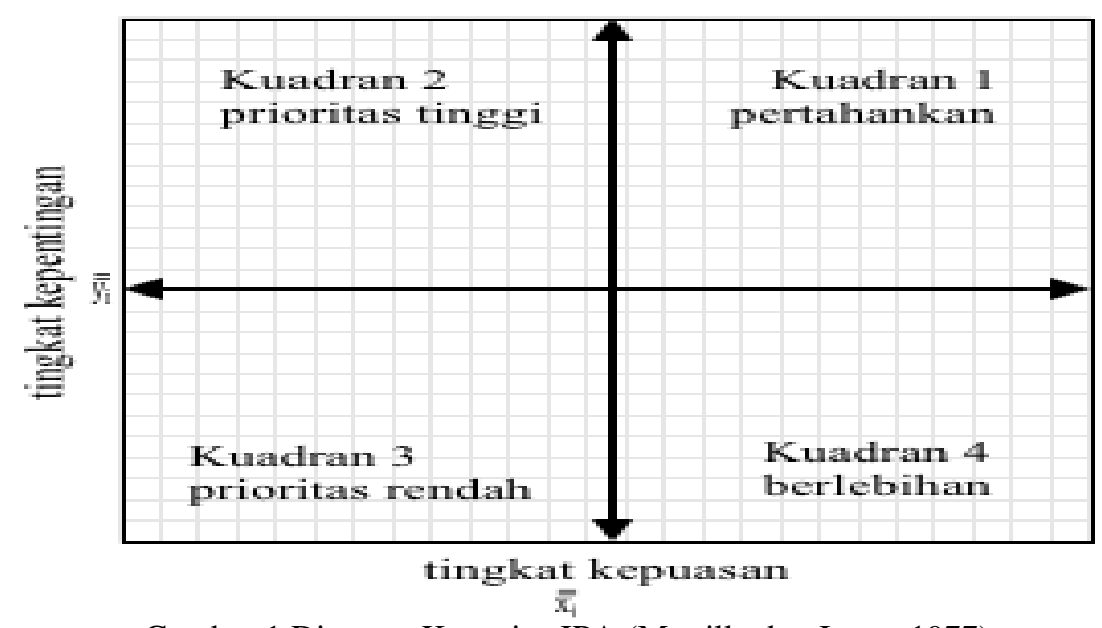

Gambar 1 Diagram Kartesius IPA (Martilla dan James 1977) 
THK Honda-Tebet memiliki luas total 22.518,00 $\mathrm{m}^{2}$, luas rumput 7.385,60 $\mathrm{m}^{2}$ (boleh diinjak), luas tanaman hias 2.318,14 $\mathrm{m}^{2}$ dengan jumlah pepohonan 1.180 pohon yang terdiri dari jenis cemara (Casuarina spp.), kecrutan (Spathodea campanulata), trembesi (Samanea saman), mahoni (Swietenia macrophyla), dan flamboyan (Delonix regia). Sebagai RTH, THK HondaTebet terbuka untuk umum selama 24 jam tidak perlu membeli tiket masuk.

THK Penjaringan memiliki total luas $30.587,34 \mathrm{~m}^{2}$, luas rumput 28.209,92 $\mathrm{m}^{2}$ (tidak boleh diinjak), dengan total jumlah pepohonan 4.000 pepohonan yang terdiri dari berbagai jenis, seperti trembesi (Samanea saman), leda (Eucalyptus deglupta), mahoni (Swietenia macrophyla), anggur laut (Coccoloba uvifera), kecrutan (Spathodea campanulata), flamboyan (Delonix regia), cemara (Casuarina spp.), yang liu (Salix babylonica). Sebagai RTH, THK Penjaringan terbuka untuk umum selama 24 jam dan tidak berbayar. Ketiga lokasi penelitian tersebut dikelola oleh Dinas Kehutanan Pemerintah Provisi DKI Jakarta.

\section{Profil dan Aktivitas Pengunjung}

Persentase responden laki-laki adalah 52,22\%, hampir seimbang dengan persentase perempuan yaitu $47,78 \%$ yang datang dari berbagai lokasi dan sebagian besar berdomisili dekat dengan tapak penelitian. Para pengunjung datang untuk berekreasi di THK/Green Open Space $(G O S)$ di tapak rekreasi dan menikmati kegiatan yang disebut dengan social cohesion oleh Peters et al. (2010) dan menimbulkan social interaction di THK yang dikunjungi sebagai tapak rekreasi. Berdasarkan penelitian ini, diketahui pola kunjungan responden pada tiga lokasi penelitian secara umum dilakukan secara berkelompok, sedangkan yang datang secara sendirian sekitar 20\%. Gambaran profil pengunjung dapat dilihat pada Tabel 1.

Tabel 1 Profil responden pengunjung dalam persen

\begin{tabular}{|c|c|c|c|c|c|}
\hline Indikator & Variabel & $\begin{array}{l}\text { Taman Kota Suropati } \\
\qquad(\mathrm{n}=240)\end{array}$ & $\begin{array}{l}\text { THK Honda-Tebet } \\
(\mathrm{n}=180)\end{array}$ & $\begin{array}{l}\text { THK Penjaringan } \\
(\mathrm{n}=180)\end{array}$ & Rata-rata \\
\hline \multirow[t]{2}{*}{ Jenis kelamin } & $\mathrm{L}(\mathrm{n}=312)$ & 50,00 & 49,44 & 57,22 & 52,22 \\
\hline & $P(n=288)$ & 50,00 & 50,56 & 42,78 & 47,78 \\
\hline \multirow[t]{2}{*}{ Status pernikahan } & (a) Single & 62,50 & 73,89 & 65,56 & 67,32 \\
\hline & (b) Menikah & 37,50 & 26,11 & 34,44 & 32,68 \\
\hline Pola kunjungan & (1) Datang sendiri & 18,94 & 17,26 & 25,13 & 20,44 \\
\hline \multirow[t]{5}{*}{ A. Weekday } & (2) Bersama teman & 22,46 & 25,36 & 24,83 & 24,22 \\
\hline & (3) Bersama keluarga & 15,73 & 16,26 & 14,70 & 15,56 \\
\hline & (4) Kelompok 3-5 orang & 15,89 & 16,12 & 12,11 & 14,71 \\
\hline & (5) Kelompok 6-10 orang & 13,53 & 12,86 & 11,42 & 12,60 \\
\hline & (6) Kelompok >10 & 13,45 & 12,14 & 11,81 & 12,47 \\
\hline \multirow[t]{6}{*}{ B. Weekend } & (1) Datang sendiri & 16,34 & 16,61 & 20,03 & 17,66 \\
\hline & (2) Bersama teman & 23,28 & 23,77 & 24,08 & 23,71 \\
\hline & (3) Bersama keluarga & 15,95 & 15,85 & 16,09 & 15,96 \\
\hline & (4) Kelompok 3-5 orang & 16,76 & 16,46 & 15,71 & 16,31 \\
\hline & (5) Kelompok 6-10 orang & 14,50 & 13,86 & 13,12 & 13,83 \\
\hline & (6) Kelompok >10 & 13,17 & 13,46 & 10,96 & 12,53 \\
\hline \multirow[t]{7}{*}{ Pekerjaan } & (a) Pelajar & 27,08 & 45,56 & 41,11 & 37,92 \\
\hline & (b) PNS & 10,42 & 4,44 & 3,89 & 6,25 \\
\hline & (c) Swasta & 42,50 & 33,89 & 40,56 & 38,98 \\
\hline & (d) TNI/Polri & 1,25 & 0,00 & 0,00 & 0,42 \\
\hline & (e) Guru/Dosen & 4,17 & 3,89 & 2,22 & 3,43 \\
\hline & (f) BUMN/BUMD & 7,50 & 1,67 & 2,78 & 3,98 \\
\hline & (g) Tidak bekerja & 7,08 & 10,56 & 9,44 & 9,03 \\
\hline \multirow[t]{6}{*}{ Pendapatan perbulan } & (a) $<1$ juta & 12,93 & 39,89 & 22,91 & 25,24 \\
\hline & (b) $1-2,5$ juta & 21,12 & 15,17 & 26,82 & 21,04 \\
\hline & (c) $2,5-5$ juta & 40,09 & 33,15 & 37,99 & 37,08 \\
\hline & (d) $5-7,5$ juta & 20,26 & 8,99 & 9,50 & 12,92 \\
\hline & (e) $7,5-10$ juta & 4,31 & 1,69 & 2,79 & 2,93 \\
\hline & (f) $>10$ juta & 1,29 & 1,12 & 0,00 & 0,80 \\
\hline \multirow[t]{6}{*}{ Pendidikan } & (a) $\mathrm{SD}$ & 0,00 & 1,11 & 2,78 & 1,30 \\
\hline & (b) SMP & 1,68 & 18,89 & 5,00 & 8,52 \\
\hline & (c) SMA & 41,18 & 50,00 & 62,22 & 51,13 \\
\hline & (d) Diploma & 16,39 & 11,11 & 8,33 & 11,94 \\
\hline & (e) Sarjana & 39,92 & 18,89 & 21,67 & 26,83 \\
\hline & (f) Lainnya & 0,84 & 0,00 & 0,00 & 0,28 \\
\hline
\end{tabular}


Kegiatan yang dominan adalah aktivitas kumpulkumpul sekitar 59\%, sementara kegiatan yang paling jarang dilakukan adalah aktivitas main sekitar 4,4\%. Kegiatan berkumpul merupakan kegiatan interaksi sosial dalam bentuk mengobrol, diskusi dan bercengkrama. Bermain adalah kegiatan dengan memanfaatkan wahana permainan yang telah disediakan oleh pengelola seperti ayunan, papan luncur dan lain sebagainya.

Di samping kegiatan sosial, kegiatan olahraga juga merupakan kegiatan yang banyak diminati oleh para pengunjung terutama saat weekend. Jenis olahraga yang paling banyak dilakukan adalah jogging, karena lebih mudah untuk dilakukan dan tidak memerlukan banyak sarana dan fasilitas, cukup memanfaatkan jalur sirkulasi di dalam taman kota dan THK saja. Ragam aktivitas

\section{Analisis Faktor Sosial dan Psikologi}

Analisis faktor sosial dan psikologi sebagai indikator penentu kepuasan pengunjung di tiga tapak penelitian dibagi menjadi lima kelompok aspek penting (aspek kontak sosial, aspek atmosfer berkegiatan, aspek aktivitas rekreasi, aspek keamanan dan keselamatan, aspek kenyamanan) dimana setiap aspek terdiri dari tujuh pengunjung taman kota dan THK dapat dilihat pada Tabel 2.

Berdasarkan hasil penelitian, secara umum kegiatan rekreasi di taman kota dan THK di DKI Jakarta tidak jauh berbeda dengan berbagai negara lain yakni: 1) olahraga, 2) relaksasi, 3) interaksi sosial dan family gathering, 4) kegiatan hobi. Arnberger (2006) menyebutkan tujuan berkunjung ke THK di Kota Lobau Wina Austria dan Kota Nopporo Jepang untuk: 1) olahraga dan kesehatan, 2) menikmati pemandangan alam dan 3) untuk rekreasi. Hasil studi rekreasi di THK Fuzhou Cina menjelaskan pengunjung THK pada umumnya lebih memilih aktivitas yang berkaitan dengan fisik dan olahraga dibandingkan aktivitas sosial seperti kontak sosial atau kumpul-kumpul (Chen et al. 2018). kriteria (Tabel 3) sehingga diperoleh total 35 kriteria. Nilai penting dan nilai kepuasan dari setiap kriteria dapat dilihat pada Tabel 3. Sebaran nilai penting dan nilai kepuasan setiap kriteria sesuai dengan skor dan posisi kuadrannya dapat dilihat pola penyebarannya secara jelas pada Gambar 2.

Tabel 2 Jenis aktivitas di taman kota dan THK di DKI dalam persen

\begin{tabular}{|c|c|c|c|c|}
\hline Aktivitas & Taman Kota Suropati & THK Honda-Tebet & THK Penjaringan & Rata-rata \\
\hline \multicolumn{5}{|l|}{ Aktivitas sosial } \\
\hline 1. Duduk & 23,78 & 26,56 & 30,41 & 26,92 \\
\hline 2. Main & 13,33 & 0,00 & 0,00 & 4,44 \\
\hline 3. Kumpul & 51,43 & 68,73 & 59,45 & 59,87 \\
\hline 4. Foto & 11,46 & 4,70 & 10,14 & 8,77 \\
\hline \multicolumn{5}{|c|}{ Aktivitas olahraga } \\
\hline 1. Badminton & 9,57 & 11,71 & 7,53 & 7,53 \\
\hline 2. Jogging & 50,99 & 72,92 & 71,48 & 71,48 \\
\hline 3. Taekwondo & 5,28 & 10,91 & 5,40 & 5,40 \\
\hline 4. Senam & 34,16 & 4,46 & 15,59 & 15,59 \\
\hline
\end{tabular}

Tabel 3 Importance Performance Analysis aspek sosial psikologi

\begin{tabular}{|c|c|c|c|c|c|c|c|c|c|c|c|}
\hline \multirow{2}{*}{ Aspek } & \multirow{2}{*}{ No } & \multirow{2}{*}{ Aktivitas } & \multicolumn{3}{|c|}{ Taman Kota Suropati } & \multicolumn{3}{|c|}{ THK Honda - Tebet } & \multicolumn{3}{|c|}{ THK Penjaringan } \\
\hline & & & Puas & Penting & Kuadran & Puas & Penting & Kuadran & Puas & Penting & Kuadran \\
\hline Kontak & 1 & Kontak okularis & 4,71 & 5,28 & 4 & 4,54 & 5,02 & 4 & 4,34 & 5,36 & 4 \\
\hline \multirow[t]{6}{*}{ sosial } & 2 & Kontak lisan & 4,98 & 5,28 & 3 & 4,74 & 5,24 & 4 & 4,63 & 5,57 & 3 \\
\hline & 3 & Saling berkenalan & 4,97 & 5,18 & 3 & 4,68 & 5,14 & 4 & 4,52 & 5,48 & 3 \\
\hline & 4 & $\begin{array}{l}\text { Terjadi diskusi (pertukaran ranah } \\
\text { kognitif) }\end{array}$ & 4,87 & 5,22 & 4 & 4,78 & 5,35 & 4 & 4,53 & 5,47 & 3 \\
\hline & 5 & Kontak seni & 4,76 & 5,32 & 4 & 4,56 & 5,32 & 4 & 4,12 & 5,42 & 4 \\
\hline & 6 & Kontak afeksi/rasa & 4,90 & 5,25 & 4 & 4,69 & 5,21 & 4 & 4,48 & 5,48 & 4 \\
\hline & 7 & Kontak sosial berintensitas lanjut & 4,84 & 5,24 & 4 & 4,89 & 5,26 & 4 & 4,59 & 5,57 & 3 \\
\hline \multirow{7}{*}{$\begin{array}{l}\text { Aspek atmosfer } \\
\text { berkegiatan }\end{array}$} & 8 & Atmosfer kebersamaan & 5,29 & 5,57 & 1 & 5,20 & 5,51 & 1 & 4,61 & 5,54 & 3 \\
\hline & 9 & Atmosfer kekeluargaan & 5,40 & 5,65 & 1 & 5,32 & 5,67 & 1 & 4,79 & 5,67 & 1 \\
\hline & 10 & Atmosfer ikatan sosial & 5,32 & 5,58 & 1 & 5,15 & 5,51 & 1 & 4,70 & 5,58 & 3 \\
\hline & 11 & Atmosfer afektif (kasih sayang) & 5,37 & 5,59 & 1 & 5,21 & 5,56 & 1 & 4,64 & 5,67 & 1 \\
\hline & 12 & Atmosfer kognitif (logika) & 5,19 & 5,56 & 1 & 5,05 & 5,54 & 1 & 4,69 & 5,64 & 1 \\
\hline & 13 & Atmosfer inspiratif (ide) & 5,34 & 5,57 & 1 & 5,14 & 5,54 & 1 & 4,84 & 5,71 & 1 \\
\hline & 14 & Atmosfer kesehatan & 5,38 & 5,69 & 1 & 5,42 & 5,83 & 1 & 4,99 & 5,79 & 1 \\
\hline \multirow{4}{*}{$\begin{array}{l}\text { Aspek aktivitas } \\
\text { rekreasi }\end{array}$} & 15 & Kualitas interaksi sosial & 4,96 & 5,40 & 3 & 4,90 & 5,49 & 4 & 4,43 & 5,51 & 4 \\
\hline & 16 & Kualitas untuk kegiatan piknik & 5,03 & 5,43 & 1 & 5,18 & 5,58 & 1 & 4,81 & 5,71 & 1 \\
\hline & 17 & Kualitas olahraga rekreasional & 4,93 & 5,41 & 2 & 5,22 & 5,71 & 1 & 4,73 & 5,58 & 3 \\
\hline & 18 & Kualitas Out-bound & 4,48 & 5,31 & 4 & 4,51 & 5,28 & 4 & 4,04 & 5,39 & 4 \\
\hline
\end{tabular}




\begin{tabular}{|c|c|c|c|c|c|c|c|c|c|c|c|}
\hline \multirow{5}{*}{ Aspek } & \multirow{2}{*}{ No } & \multirow{2}{*}{ Aktivitas } & \multicolumn{3}{|c|}{ Taman Kota Suropati } & \multicolumn{3}{|c|}{ THK Honda - Tebet } & \multicolumn{3}{|c|}{ THK Penjaringan } \\
\hline & & & Puas & Penting & Kuadran & Puas & Penting & Kuadran & Puas & Penting & Kuadran \\
\hline & 19 & Photography & 4,74 & 5,46 & 2 & 4,70 & 5,44 & 4 & 4,08 & 5,39 & 4 \\
\hline & 20 & Kualitas aktivitas terkait hobi & 5,14 & 5,48 & 1 & 5,22 & 5,66 & 1 & 4,61 & 5,54 & 3 \\
\hline & 21 & Kualitas wahana yang disediakan & 5,09 & 5,44 & 1 & 5,22 & 5,64 & 1 & 4,58 & 5,64 & 1 \\
\hline Aspek & 22 & Gangguan kriminalitas & 4,20 & 5,30 & 4 & 4,59 & 5,44 & 4 & 3,84 & 5,44 & 4 \\
\hline keamanan & 23 & Gangguan antar kelompok & 4,33 & 5,42 & 4 & 4,63 & 5,52 & 2 & 4,07 & 5,66 & 2 \\
\hline dan & 24 & Gangguan satwa liar & 4,43 & 5,39 & 4 & 4,67 & 5,87 & 2 & 3,92 & 5,52 & 4 \\
\hline keselamatan & 25 & Keamanan bagi anak & 4,75 & 5,50 & 2 & 5,02 & 5,72 & 1 & 4,21 & 5,57 & 4 \\
\hline & 26 & $\begin{array}{l}\text { Keamanan bagi perempuan dan } \\
\text { lansia }\end{array}$ & 4.76 & 5.47 & 2 & 5.01 & 5.68 & 1 & 428 & 558 & 4 \\
\hline & 27 & Keamanan bagi disabilitas & 4,87 & 5,54 & 2 & 4,94 & 5,76 & 1 & 4,36 & 5,67 & 2 \\
\hline & 28 & Ketersediaan SDM pengamanan & 4,98 & 5,50 & 2 & 5,10 & 5,79 & 1 & 4,52 & 5,68 & 1 \\
\hline Aspek & 29 & Rentang area kegiatan & 4,91 & 5,30 & 4 & 4,74 & 5,37 & 4 & 4,65 & 5,58 & 3 \\
\hline kenyamanan & 30 & Rentang kegiatan yang dilakukan & 4,97 & 5,38 & 3 & 4,92 & 5,43 & 4 & 4,86 & 5,76 & 1 \\
\hline & 31 & Rentang kepadatan pengunjung & 5,01 & 5,27 & 3 & 4,85 & 5,52 & 2 & 4,63 & 5,77 & 1 \\
\hline & 32 & $\begin{array}{l}\text { Kenyamanan dalam ketertiban } \\
\text { umum }\end{array}$ & 5,01 & 5,43 & 1 & 5,00 & 5,54 & 1 & 4,68 & 5,65 & 1 \\
\hline & 33 & Kesempatan pemakaian fasilitas & 4,96 & 5,42 & 1 & 4,91 & 5,47 & 4 & 4,67 & 5,73 & 1 \\
\hline & 34 & $\begin{array}{ll}\text { Batasan waktu } & \text { saat } \\
\text { berkegiatan/rekreasi } & \end{array}$ & 5,00 & 5,39 & 3 & 4,99 & 5,51 & 1 & 4,68 & 5,74 & 1 \\
\hline & 35 & Ketersediaan fasilitas dasar & 5,10 & 5,41 & 1 & 5,13 & 5,63 & 1 & 4,75 & 5,86 & 1 \\
\hline
\end{tabular}

Aspek sosial Taman Kota Suropati

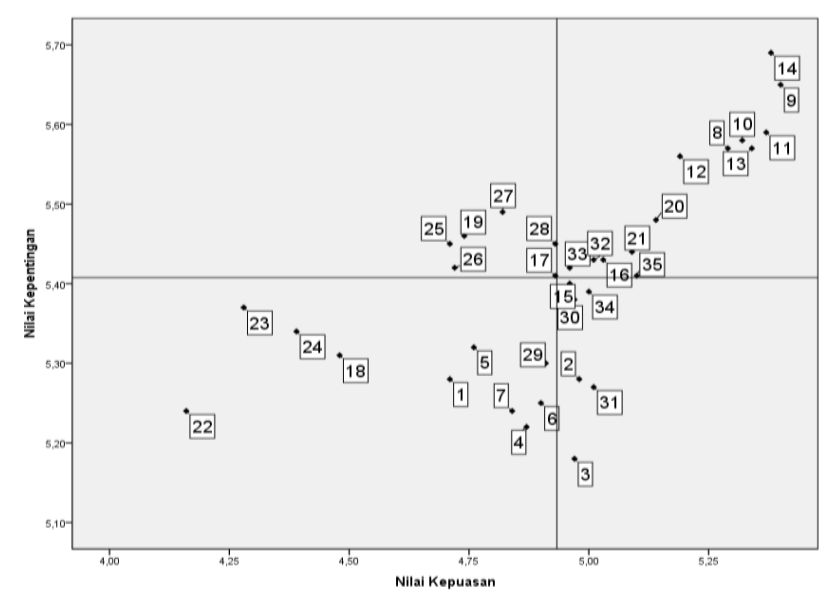

Aspek sosial THK Honda-Tebet

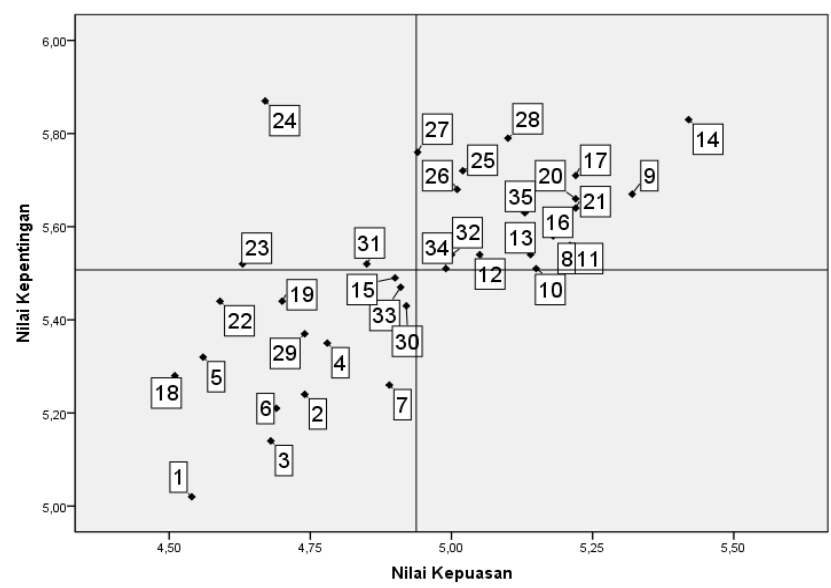

Aspek sosial THK Penjaringan

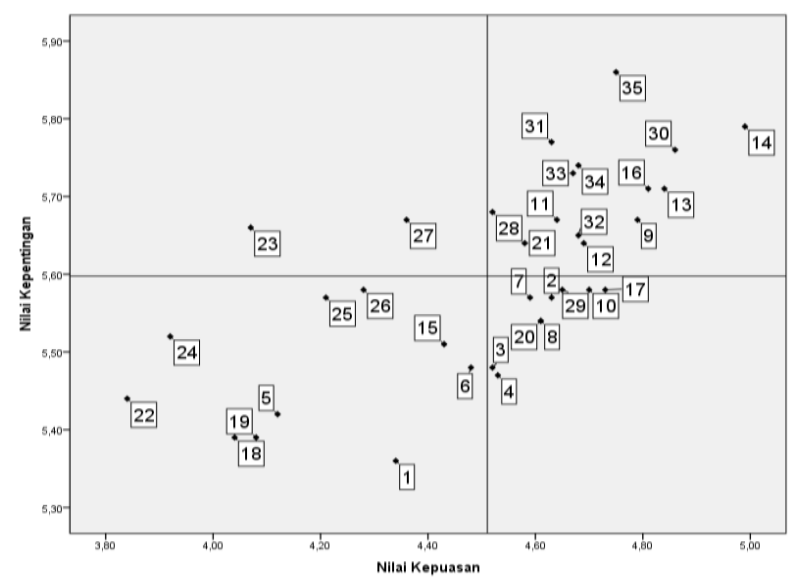

Gambar 2 Kuadran IPA sosial dan psikologi 
Berdasarkan hasil penelitian di ke-3 tapak rekreasi, dari 35 indikator faktor sosial dan psikologi diketahui sebagian besar berada dalam kuadran 1, kemudian dalam kuadran 3 dan 4, sedikit sekali yang berada dalam kuadran 2. Aspek atmosfer berkegiatan dan aspek kenyamanan secara umum berada pada kuadran 1 . Kebijakan pengelolaan yang ditempuh sebaiknya mempertahankan kondisi dan kualitas aspek atmosfer berkegiatan dan aspek kenyamanan pada taman kota dan THK agar kepuasan pengunjung tidak menurun sekaligus menjaga kelestarian kehati dan tapak rekreasi. Selanjutnya indikator yang menjadi prioritas utama (tantangan) untuk ditingkatkan performanya adalah indikator (atribut) pada kuadran 2 yang terdiri dari beberapa indikator dari aspek kontak sosial dan aspek keamanan serta kenyamanan.

Berdasarkan hasil penelitian, diketahui secara umum skor kepuasan pengunjung dari 3 faktor sosial $(1,2,3)$ dan faktor psikologi $(4,5)$ berada pada angka di atas 4 atau bernilai positif. Sebaran skor kepuasan pengunjung pada tiga lokasi penelitian dapat dilihat pada Gambar 3.

Hasil penelitian memperlihatkan bahwa skor aspek kontak sosial pada Taman Kota Suropati adalah 4,86, sedangkan THK Honda Tebet adalah 4,78 dan THK
Penjaringan 4,46. Interaksi sosial atau kontak sosial memang lebih intensif dilakukan di Taman Kota Suropati, hal ini karena karakteristik pengunjung yang sebagian besar memiliki latar pendidikan menengah dan pendidikan tinggi. Skor nilai kepuasan total aspek atmosfer berkegiatan adalah sebesar 5, 33 untuk Taman Kota Suropati, 5,22 untuk THK Honda-Tebet dan 4,75 untuk THK Penjaringan. Aspek atmosfer berkegiatan di Taman Kota Suropati memiliki skor paling tinggi di antara ketiga lokasi penelitian, sesuai dengan status kondisi Taman Kota Suropati yang merupakan taman kota yang sudah sangat baik dalam pengelolaannya. Berdasarkan hasil penelitian, secara umum nilai kepuasan faktor atsmosfer berkegiatan pada ketiga tapak rekreasi yang diteliti menunjukkan skor paling tinggi dibanding aspek sosial dan psikologi serta lainnya; hal ini menunjukkan betapa pentingnya kebijakan pengelolaan yang dibutuhkan untuk dapat mengimplementasikan arah yang bijaksana oleh pihak pengelola dalam mempertahankan situasi dan kondisi tapak rekreasi yang sudah baik dengan meningkatkan performa yang menjadi tantangan bagi ketiga tapak rekreasi tersebut, yakni aspek keamanan dan keselamatan serta aspek kenyamanan (agar terjadi repetisi kunjungan).

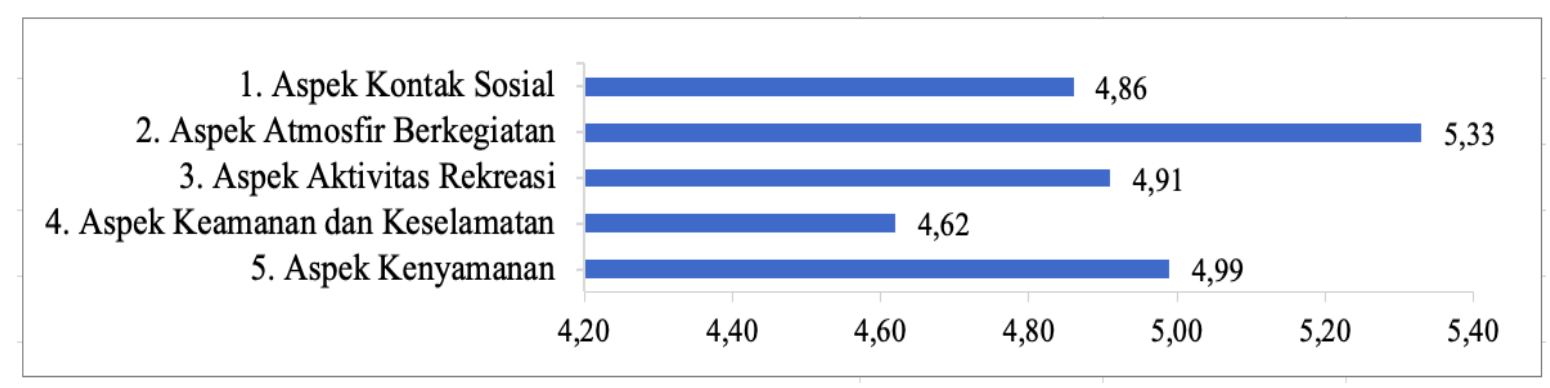

(a)

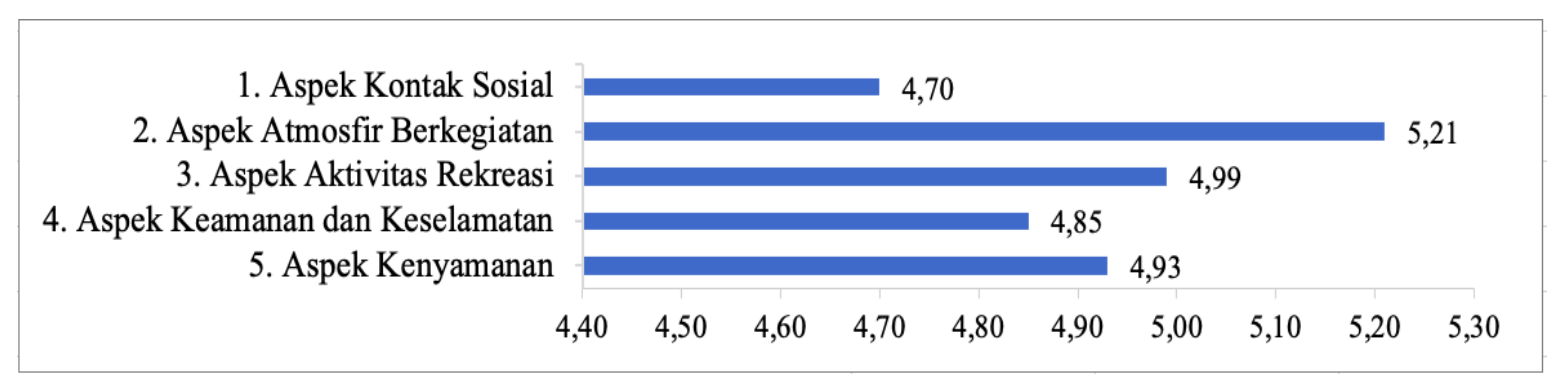

(b) 


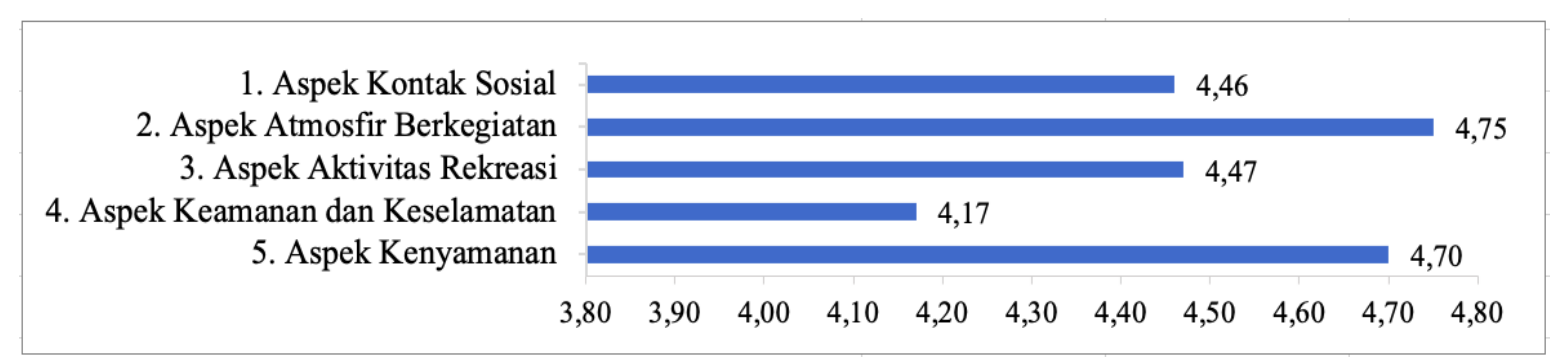

(c)

Gambar 3 Diagram skor faktor kepuasan sosial dan psikologi, (a) Taman kota Suropati, (b) THK Honda Tebet, (c) THK Penjaringan

Tabel 4 Customer Satisfaction Index

\begin{tabular}{ccccc}
\hline No. & Lokasi & Weekdays & Weekends & Rata-rata \\
\hline 1. & Taman Kota Suropati & 69,93 & 71,29 & 70,61 \\
2. & THK Honda - Tebet & 71,26 & 69,92 & 70,59 \\
3. & THK Penjaringan & 63,59 & 65,35 & 64,47 \\
\hline
\end{tabular}

Berdasarkan hasil penelitian, skor kepuasan aspek aktivitas berekreasi di ketiga THK adalah sebesar 4,91 di THK Suropati, 4,99 untuk THK Honda Tebet, dan 4,47 untuk THK Penjaringan Aktivitas berekreasi pada taman kota dan THK di DKI Jakarta secara umum sudah cukup baik. Selanjutnya skor kepuasan aspek keamanan dan keselamatan di THK Suropati dan THK Penjaringan yaitu 4,62 dan 4,17. Sedangkan di THK Honda-Tebet memiliki skor 4,8 ; secara umum skor kepuasan atas aspek keamanan dan keselamatan di ketiga lokasi tapak rekreasi yang diteliti memiliki skor yg paling rendah dari masing-masingnya (sementara aspek ini memiliki kepentingan yang tinggi dalam kebutuhannya). Pada kenyataannya, kondisi keamanan dan keselamatan di Taman Kota Suropati memiliki ketersediaan fasilitas keamanan yang sangat memadai (excellent) dan dijaga 24 jam, dengan jumlah petugas yang sangat cukup. Sarana monitoring keamanan sudah tersedia perangkat CCTV untuk memonitor dan tindakan antisipasi terhadap keadaan lingkungan di pemukiman sekitarnya. Akan tetapi, secara zonasi area ini masuk ke wilayah "Ring-1" karena berada di tengah area tempat tinggal para pejabat tinggi negara menjadikan tapak rekreasi ini berkemungkinan besar masuk dalam zona yang menjadi target terorisme (hal ini yang menimbulkan rasa khawatir bagi para pengunjung).

Hasil penelitian menunjukkan skor aspek kenyamanan di tiga lokasi THK berada pada urutan kedua setelah aspek astmofer berkegiatan. Pada THK Honda-Tebet memiliki skor kepuasan kenyaman sebesar 4,95 , di THK Suropati 4,99 dan di THK Penjaringan adalah 4,7. Berdasarkan hasil penelitian, secara umum pengunjung sudah merasa nyaman berekreasi di ketiga THK di DKI Jakarta. Tingkat kenyamanan pengunjung THK sudah relatif bagus, hal ini ditunjukkan dengan tidak ditemukannya unsur vandalisme, premanisme, anak jalanan dan pengemis di lokasi THK. Kejadian kriminalitas dan kejahatan juga jarang ditemukan di lokasi ketiga THK penelitian ini.

\section{Customer Satisfaction Index}

Berdasarkan hasil penelitian, nilai CSI sosial dan psikologi dari tiga tapak penelitian yang paling tinggi di Taman Kota Suropati dan yang paling rendah di THK Penjaringan. Secara umum niai CSI pada saat weekends lebih tinggi daripada pada saat weekdays kecuali pada THK Honda Tebet yang memiliki CSI yang lebih besar pada saat weekdays dibanding saat weekends. Data CSI di ketiga tapak penelitian dapat dilihat pada Tabel 4.

THK $(G O S)$ merupakan elemen yang penting bagi lingkungan padat penduduk dan dapat digunakan untuk mengasingkan diri kondisi yang penat akibat beban kerja. Disamping itu THK mampu menyediakan tempat yang relatif tidak terlalu ramai namun disisi lain dapat dijadikan wahana untuk kontak sosial (Hammitt 2002).

Penelitian yang dilakukan oleh Chen et al. (2018) tentang kepuasan pengunjung di THK Fuzhou Cina menunjukkan bahwa faktor biofisik masih menjadi faktor utama penentu kepuasan pengunjung. Adapun aspek sosial psikologi seperti tingkat kenyamanan, fasilitas dasar, dan tingkat keramaian atau kepadatan pengunjung menempati urutan menengah dan bawah dalam memenuhi kepuasan pengunjung. Atas dasar tersebut maka perlu ada pembenahan terhadap aspek sosial dan psikologi dalam rekreasi di THK untuk meningkatkan tingkat kepuasan pengunjung. Faktor biofisik, sosial dan psikologi juga pada akhirnya akan menentukan dominasi aktivitas rekreasi di THK. Apabila aspek biofisik yang menjadi tantangan utama oleh pihak pengelola THK maka aktivitas rekreasi THK cenderung kepada aktivitas olahraga dan relaksasi untuk kesehatan. Adapun apabila faktor sosial dan psikologi yang menjadi tantangan utama maka aktivitas rekreasi di THK cenderung bersifat untuk interaksi sosial antar sesama pengunjung. 


\section{Hubungan Kepuasan Pengunjung dengan Faktor Sosial dan Psikologi}

Analisis korelasi dilakukan untuk mengetahui hubungan antar faktor apakah saling berhubungan atau tidak. Hasil korelasi dari kelima aspek disajikan dalam Tabel 5. Berdasarkan Tabel 5, hasil analisis korelasi dapat disebutkan bahwa semua aspek dalam faktor sosial dan psikologi memiliki hubungan yang cukup signifikan. Koefisien korelasi bernilai positif dan mendekati angka 1. Selanjutnya untuk menduga rumus antara tingkat kepuasan dengan faktor sosial dan psikologi dirumuskan model matematis berupa analisis regresi berganda. Model matematis kepuasan pengunjung dengan nilai penting faktor sosial dan psikologi dirumuskan sebagai berikut: $\mathrm{Y}=1,954+0,050 \mathrm{x}_{1}+\mathbf{0 , 1 8 2} \mathrm{x}_{2}+\mathbf{0 , 1 2 6} \mathbf{x}_{3}+\mathbf{0 , 0 3 7} \mathbf{x}_{4}+$ $0,147 \times 5$

Diketahui $\mathrm{Y}$ adalah variabel kepuasan pengunjung dan $\mathrm{X}_{1}-\mathrm{X}_{5}$ adalah variabel nilai penting dengan rincian: $\mathrm{X}_{1}$ ) aspek kontak sosial, $\mathrm{X}_{2}$ ) aspek atmosfer berkegiatan, $\mathrm{X}_{3}$ ) aspek aktivitas rekreasi, $\mathrm{X}_{4}$ ) aspek keamanan dan keselamatan, dan $\mathrm{X}_{5}$ ) aspek kenyamanan. Dari rumus regresi tersebut dapat diketahui bahwa variabel $\mathrm{X}_{2}$ yaitu aspek atmosfer berkegiatan memiliki koefisien yang paling besar. Sedangkan aspek keamanan dan keselamatan yaitu $\mathrm{X}_{4}$ merupakan variabel yang memiliki nilai koefisien yang paling rendah. Ringkasan analsisi regresi tentang faktor sosial dan psikologi terhadap kepuasan pengunjung selanjutnya dapat dilihat pada Tabel 6.

Berdasarkan penelitian ini, diketahui bahwa aspek kontak sosial $\left(\mathrm{X}_{1}\right)$ serta aspek keamanan dan keselamatan $\left(\mathrm{X}_{4}\right)$ masih dianggap kurang oleh sebagian pengunjung yang mengakibatkan nilai variabel $\mathrm{X}_{1}$ dan $\mathrm{X}_{4}$ tidak signifikan. Adapun hal yang menyebabkan kedua aspek tersebut tidak signifikan karena lokasi taman kota/THK yang berada di tengah pemukiman kaum elit politik dan pemerintahan (Taman Kota Suropati di Jakarta Pusat, well established area), ataupun THK yang lokasinya di pemukiman kaum menengah atas (THK Honda-Tebet di Jakarta Selatan, established area), dan juga pada THK yang terletak di pemukiman kumuh (THK Penjaringan di Jakarta Utara, less establihed area), sehingga menyebabkan pengunjung merasa kurang aman dalam situasi dan kondisi yang ada. Pada well established area dan established area; karena mayoritas pengunjung adalah kalangan menengah atas dan berada di lokasi strategis yang menimbulkan kekhawatiran lokasi tersebut dapat menjadi target utama aksi teroris dan kejahatan, sementara pada less established area muncul rasa kurang aman dan khawatir selama di lokasi karena keberadaannya di tengah pemukiman kumuh yang kehidupan sosial sekitar THK tidak cukup memadai fasilitas keamanan lingkungannya. Model analisis regresi faktor sosial dan psikologi terhadap kepuasan pengunjung dari tiga tapak penelitian diperoleh persamaan yang mendekati kondisi sesungguhnya, hal ini ditunjukkan dari dari analisis sisaan persamaan regresi seperti terlihat pada Gambar 4. Gambar 4 memperlihatkan bahwa kurva dan histogram membentuk kurva normal, artinya tidak ada masalah pada sisaan persamaan regreasi. Selanjutnya terlihat bahwa sisaan berada di garis normal, artinya tidak ada pencilan dari data tersebut.

Tabel 5. Koefisien korelasi silang aspek sosial dan psikologi penentu kepuasan pengunjung di THK.

\begin{tabular}{|c|c|c|c|c|c|}
\hline \multicolumn{6}{|c|}{ Correlations Spearman's rho } \\
\hline & $\mathrm{X}_{1}$ & $X_{2}$ & $X_{3}$ & $\mathrm{X}_{4}$ & $\mathrm{X}_{5}$ \\
\hline $\mathrm{X}_{2}$ &, $699^{* *}$ & & & & \\
\hline $\mathrm{X}_{3}$ &, $585^{* *}$ &, $585^{* *}$ & & & \\
\hline $\mathrm{X}_{4}$ &, $426^{* *}$ &, $493^{* *}$ &, $626^{* *}$ & & \\
\hline $\mathrm{X}_{5}$ &, $588^{* *}$ & $629^{* *}$ &, $575^{* *}$ &, $569^{* *}$ & \\
\hline $\mathrm{Y}$ & $460^{* * *}$ &, $506^{* *}$ & $456^{* *}$ & $420^{* *}$ &, $472^{* *}$ \\
\hline
\end{tabular}

**. Correlation is significant at the 0,01 level (2-tailed).

Keterangan : $\mathrm{X}_{1}=$ aspek kontak sosial, $\mathrm{X}_{2}=$ aspek atmosfer berkegiatan, $\mathrm{X}_{3}=$ aspek aktivitas rekreasi, $\mathrm{X}_{4}=$ aspek keamanan dan keselamatan, $\mathrm{X}_{5}=$ aspek kenyamanan.

Tabel 6 Analisis regresi faktor sosial dan psikologi terhadap kepuasan pengunjung pada tiga tapak penelitian

\begin{tabular}{crrrrr}
\hline Variabel & B & Std. Error & Beta & t & Sig \\
\hline (Constant) & 1,954 &, 158 & & 12,398 &, 000 \\
x1 &, 050 &, 032 &, 073 & 1,553 &, 121 \\
x2 &, 182 &, 036 &, 256 & 5,063 &, 000 \\
x3 &, 126 &, 035 &, 165 & 3,587 &, 000 \\
x4 &, 037 &, 025 &, 060 & 1,442 &, 150 \\
x5 &, 147 &, 034 &, 197 & 4,330 &, 000 \\
\hline
\end{tabular}

Keterangan: Taraf nyata yang digunakan (alpha) adalah $0,05, \mathrm{X}_{1}=$ aspek kontak sosial, $\mathrm{X}_{2}=$ aspek atmosfer berkegiatan, $\mathrm{X}_{3}=$ aspek aktivitas rekreasi, $\mathrm{X}_{4}=$ aspek keamanan dan keselamatan, $\mathrm{X}_{5}=$ aspek kenyamanan. 

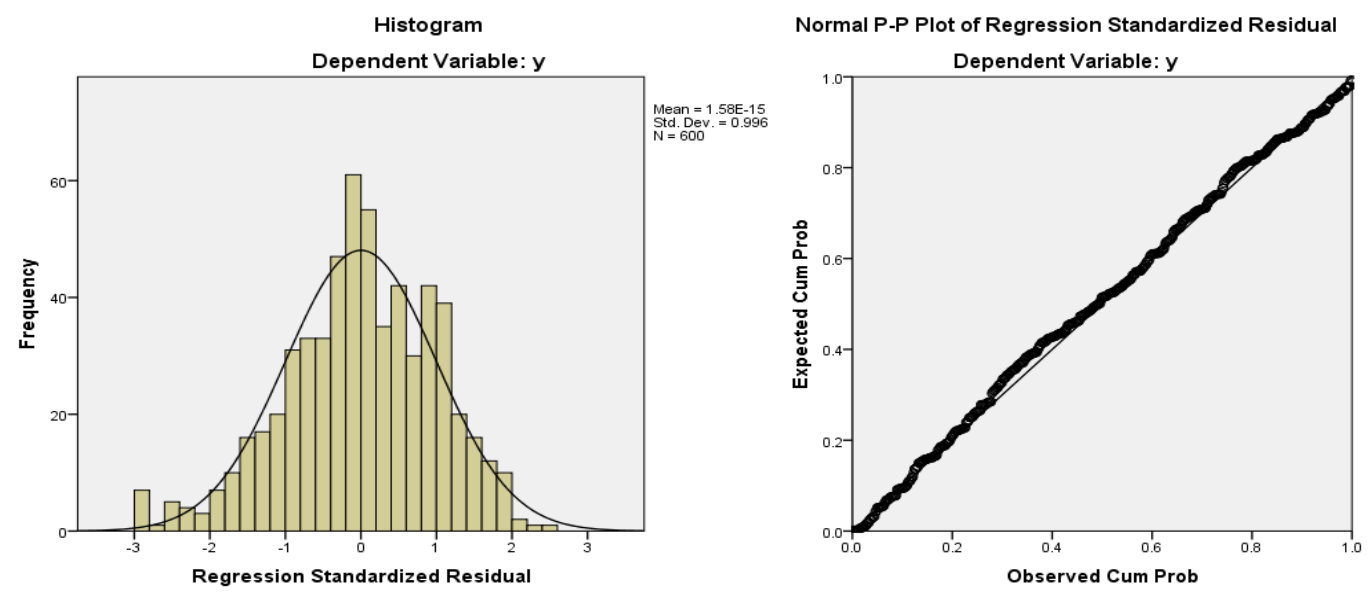

Gambar 4 Kurva dan histogram sisaan persamaan regresi

\section{SIMPULAN}

Berdasarkan hasil penelitian pada tiga tapak rekreasi (Taman Kota Surapati, THK Honda-Tebet, THK Penjaringan) atas tiga faktor sosial (aspek kontak sosial, aspek atmosfer berkegiatan, aspek aktivitas berekreasi) dan dua faktor psikologi (aspek keamanan dan keselamatan, aspek kenyamanan) sebagai penentu kepuasan pengunjung; secara umum di ketiga tapak tersebut aspek atmosfer berkegiatan menunjukkan skor yang paling tinggi karena nilai kepentingan dan kepuasannya positif (dalam kuadran 1 Diagram Kartesius) sehingga situasi dan kondisinya patut untuk dipertahankan. Aspek keamanan dan keselamatan dianggap masih kurang oleh sebagian besar pengunjung sementara nilai kepentingannya tinggi (dalam kuadran 2 Diagram Kartesius), atas hal tersebut dibutuhkan perhatian dan upaya untuk meningkatkan nilai kepuasannya. Jika aspek keamanan dan keselamatan dapat ditingkatkan skor kepuasannya, maka harapan bahwa pengunjung tapak rekreasi akan mengulangi kunjungannya di tempat yang sama untuk datang berekreasi dapat tercapai.

\section{DAFTAR PUSTAKA}

Algifari.2016. Mengukur Kualitas Layanan. Cetakan ke 1. Yogyakarta: BPFE.

Aritonang RI. 2005. Kepuasan Pelanggan. Jakarta: Gramedia Pustaka Utama.

Arnberger A. 2006. Recreation Use of urban forests: an inter-area comparison. Urban Forestry and Urban Greening. 4(3-4):135-144. https://doi.org/10.1016/j.ufug.2006.01.004

Avenzora R. 2008. Ekoturisme - Evaluasi tentang konsep. Di dalam Avenzora R, editor. Ekoturisme Teori dan Praktek. Aceh: BRR NAD-Nias.

Berry BJL. 1963. Commercial structure and commercial blight: Retail pattern and process in the city of
Chicago, in Department of Geography Research Paper 85. Chicago: University of Chicago.

Chen B, Qi X, Qiu Z. 2018. Recreational use of urban forest parks: a case study in Fuzhou National Forest Park, China. Journal of Forest Research. 23(3):183189. https://doi.org/10.1080/13416979.2018.1432304

Deng J, Andrada R, Pierskalla C. 2017. Visitor's and resident's perceptions of urban forests for leisure in Washington D.C. Urban Forestry and Urban Greening. 28:1-11. https://doi.org/10.1016/j.ufug.2017.09.007

Eriksson L, Nordlund A. 2013. How Is setting prefrerence related to intention to engage in forest reaction activities?. Urban Forestry and Urban Geening. 12:481-489.

Fellegi IP. 2003. Survey Methods and Practices Statistic. Ottawa: Statistics Canada's National Contact Centre.

Hammit WE. 2002. Urban Forest and Parks As Privacy Refuges. Journal of Arboriculture. 28 : 19- 26.

Harris CD, Ullman Fl. 1945. The Nature of Cities. The Annals of the American Academi of Political and Society Science. 242(1):7-17.

Kabisch N, Qureshi S, Haase D. 2015. Humanenvironment interactions in urban green spaces a systematic review of contemporary issues and propects for future research. Environmental Impact Assesment Review. 50:25-34.

Konijnendijk CC. 2003. A decade of urban forestry in Europe. Forest Policy and Economics. 5(2):173-186. https://doi.org/10.1016/S.1389-9341(03)00023-6

Konijnendijk CC, Sadio S, Randrup TB, Schipperijn J. 2004. Urban and peri-urban forestry in a development context - strategy and implementation. Journal of Arboriculture. 30(5):269-275.

Martilla J, James J.1977. Importance - performance analysis. Journal of Marketing. 14:77-79.

Peters K, Elands B, Buijs A. 2010. Social interaction in urban parks : stimulating social cohesion?. Urban Forestry and Urban Greening. 9:93-100. 
Ratcliff RU. 1949. Urban Land Economics. New York: McGraw Hill Book Co.

Sanesi G, Lafortezza R, Marziliano PA, Ragazzi A, Mariani L. 2007. Assessing the current status of urban forest resources in the context of Parco Nord, Milan, Italy. Landscape Ecol Eng. 3:187-198.

Santos T, Mendes RN, Vasco A. 2016. Journal of outdoor recreation and tourism recreational activities in urban parks: spatial interactions among users. Journal of Outdoor Recreationand Tourism. 15:1-9. https://doi.org/10.1016/j.jort.2016.06.001

Shin WS, Kwon HG, Hammitt WE, Kim BS. 2005. Urban forest park use and psychosocial outcomes: a case study in six cities across South Korea. Scandinavian Journal of Forest Research. 20:441447.
Sugiyono. 2012. Metode Penelitian Kuantitatif-Kualitatif dan $R \& D$. Bandung: Alfabeta.

Tabbush P, O'Brien L. 2003. Health and Well-being. Trees, Woodlands and Natural Spaces. London: Forestry Commission.

Wang YC, Lin JC, Liu WY, Lin CC, Ko SH. 2016. Investigation of visitors' motivation, satisfaction and cognition on Urban Forest Parks in Taiwan. Journal of Forest Research. 21(6):261-270. https://doi.org/ 10.1007/s10310-016-0543-4.

Wilkes-Allemann J, Pütz M., Hirschi C, Fischer C. 2015. Conflict situations and response strategies in Urban Forests in Switzerland. Scandinavian Journal of Forest Research. 30(3):204-216. https://doi.org/10.1080/02827581.2014.1002217. 